\section{$1 \mathrm{M} 1115$}

\section{粘菌 2 次元培養系における生理学的側面と細胞分化} との関係

○澤井哲 1 、平野㓮史 ${ }^{2}$ 、前田靖男 ${ }^{2}$ 、沢田康次 ${ }^{3}$ ( 1 東北 大・院情報、2 東北大·院理、3 東北大·通研）

細胞性粘菌の細胞塊を 2 次元的に拘束して発生を解析寸る、いわゆる 2 次元培盖系は粘菌発生初期の分化機構を解析寸る上で傮れた実験系 を提供する。これまでに、2次元培養系において数分間で出現する、 高速明暗パターンが皮応一搪散機構によるものであることを、酸素境 界条件や温度に対するパターンの依存性を調べることで、その実験的 証拠を提供した。また同時心、高速パ夕ーンの酸素謴度依存性や呼吸 活性との密接な関連、さらにはこのパターンの暗層部に执いて管状の 細胞分化パターンが見られることなどがつきとめられた。これらの結 果を総合すると、高速パターンそのものはマウンド初期に想定される プレパターンそのものではないものの、位置依存的な行化機構に対し て境界条件を設定していることが示唆される。事奏、これまでにも移 動体や回転培養系なとににおいても、酸素や温度が分化比率に大きく影 竜を与えることが報告されており、それらとの関保も注目される。し たがってこの系では、分化比辣に影隌を与えるこれら酸素濃度や温度 などのマクロパラメータによって、高速パターンを制御することで、 細胞性粘菌の分化パターン変化を解析することが可能であるため、位 置依存的な分化機構の力学系構造の垁験的な検証に向门て新たな材料 を提供することが期待できる。以上の目的に向け、今匝我々は高速パ ターン化に伴う細胞の生理学的な側面を細胞内カルシウムと $\mathrm{pH}$ の変 化として詳細に解析することで、勫胞しべルにおけるより定量的な特 徵付けを行った。さらにその結果と分化との関係、また通常の寒天培 地上に掠ける発生との関連について考察する。

S.Sawai, T.Hirano, Y.Maeda and Y.Sawada: Physiological responses during Dictyostelium 2-D rulturing and its relation to differentiation

\section{$1 \mathrm{M} 1145$}

$$
\text { 幹細胞システムのダイナミクス }
$$

\author{
○古澤力、金子邦彦 (束大院総合)
}

多細胞生物における細胞多様化の過程を理解するために、幹細胞シス テムのタイイミクスに注目する。幹細胞とは、自己複製と分化の両方 の能力をもつ細胞のことで、通常生体では、造血幹細胞のように増殖 できない分化した細胞 (例：赤血球)をその增殖・分化によって供給 している。しかし、ヒドラやプラナリアなど原始的な多細胞生物の再 生産の過程が幹紐胞のダイナミクスによって支之られていることや、 多くの再生の過程がこの幹細胞的なダイナミクスを持つ細胞に支配さ れることは、このダイナミクスが緗胞が多様化するもっとも基本的な 過程であることを示している。

実験的な研究から、さまざまな幹細胞システムに共通にみられる性質 として、次の 2 つが举げられる。まず、幹細胞の分化はシグナル分子 などの外部からの因子によって完全に制御されずに自発的に起こるも のであり、その振舞いはしばしば確率的である。また、分化の頻度は 状況によって制御され、それによって細胞集団レベルでの安定性が維 持されている。

本研究では、多紐胞生物を内部に反応タイイミクスを持った細胞が相 互作用している系として捉えると、その内部ダイナミクスが複雑な非

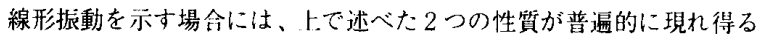
ことを、簡単なモデルを用いた計算機実験によって示す。また、この 相互作用に基ついた細胞多様化の過程において、幹細胞的な性質を持 つ紐胞は、多数の化学物質が共存している複誰に振動している内部多 イナミクスを持ち、またそこから分化してくる細胞は相対的に少数の 化学物質からなる単純な内部多イナミクスを持つことが示された。こ のことは、細胞の「幹細胞らしさ (未分化度)」を測る量として、この 内部ダイナミクスの複雑さが有効であることを示唆している。

C. Furusawa and K. Kaneko) : Dynamics of Stem Cell System

\section{$1 \mathrm{M} 1130$}

Cell type regulation in Dictyostelium: correlation between prestalk proportion and spatial pattern

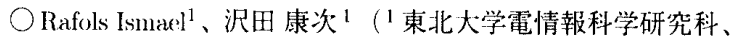
2 東北大学電気通信研究所)

Cell type differentiation of Dictyostelium discoideum is known to be highly regulative up to the late stages of development. In the migrating slug. When differentiation is still reversible, a cell type pattern is former along an anterior-posterior axis. If either the interior region of the slug (consisting of prestalk (ells) or the posterior region (mainly prespore cells) is removed, some of the remaining cells transdifferentiate into the other cell type until a new stable slug is formed On the other hand. as the size of the slugs varies from less than $10^{3}$ to more than $10^{5}$ ecolls, the spatial pattern of the slug remains qualitatively the same. These observations had made popular the proportion requlation hypothesis. which state's that the proportion of cell-types in Dictyostelium is regulated to have a constant value. By using a labile $\beta$-galactosidase as a reporter of the expression of the prestalk cell sperific gene ermA. we have quantitavely examined the proportion of cell-types and the spatial pattern of differentiation for: (i) a population of slugs of size from $\sim 10^{3}$ to $\sim 10^{5}$ (ells; (ii) slugs undergoing a regeneration process after removal of one of the cell types. It has been fomd that the prestalk proportion in natural slugs is size dependent and correlates with the shape of the sing. In regeneration experiments after amputation of the whole posterior region, it has been found that the initial prestalk proportion and shape are partially recovered in 12-18 hours but but none of them reaches their initial value. From these results we concinde that the proportion of prestalk cells in a slug is not univocally determined: a wide range of prestalk proportions below the limiting casse is stable. We show that a spatial development of a model based on a prestalk inducing morphogen can account for some of the observations.

Ismael Rafols and Yasuji Sawada : Cell type regulation in Dictyostelium: correlation between prestalk proportion and spatial patterm

\section{$1 \mathrm{M} 1315$ \\ 粘菌変形体の管ネットワークの幾何}

○中堭俊之 ${ }^{1}$ 、旦田 裕康 ${ }^{1.2 .3}$ ( ${ }^{1}$ 理研 - 局所時空間機能、 ${ }^{2}$ 理 研・制御系理諭、3 北大·電子研)

粘菌変形体は、巨大なアメーバ様生物で、特徵的な形態を持つ。先端 部はシート状であり、その寸ぐ後方は管構造の細かいネットワーク状 を呈し、さらに後方では大まかなネットワーク状であり、最後部では 三本の管構造のみとなる。この形態的特徽は、移動運動（時速 $1 \mathrm{~cm}$ 程度）の際に変らないように見えるが、実際軼的な平衡状態にあ る。すなかち、先端部でシート状形態から細かい管不ットワークが生 成し、その後方部ではネットワークのメッシュサイズの粗大化が進衍 し、ついには最後部で管が消滅する。これらの過程の絶え間ない継続 の上に、変形体は移動運動を実現する。このように、管ネットワーク のダイナミックな形態形成は、移動運動と密接に関連する。管の中で は、原形質が激しく流れている。この流れは、流れの向きが周期的に 反転するので往復原形質流動と呼ばれている。往復流動は、変形体の どこでも起きて扔り、変形体全体にわたる原形質の效率よい混合を可 能にしている。原形質の交換は細胞内の情報交換に一役加って掞り、 従って、交形体が一つの個体として、つまりまとまりある一つのシス テムとして、振る舞うのに役立っている。管ネットワークの幾何学的 性質は、变形体内の情報交換にも変形体の移動運動にも重要な意義を 持っている。ここで、我々は、管ネットワークの幾何学的性質を報告 する。細長く曲がりくねった経路の中を逼う粘菌を観察したところ、 管の配置によって迷路を解く事ができることがわかった。

T.Nakagaki and H.Yamada: Gometry of tube-network in the Physarum plasmodium 